\title{
Faktor yang Mempengaruhi Preferensi Konsumen Batik Tulis “Tanjung Bumi” Di Galeri Tresna Art Bangkalan
}

\author{
Eilmiy Sabila*, Esin Sintawati, Sri Eko Puji Rahayu \\ Universitas Negeri Malang, Jl. Semarang No. 5 Malang, Jawa Timur, Indonesia \\ *Penulis korespondensi, Surel: esin.sintawati.ft@um.ac.id
}

Paper received: 03-01-2021; revised: 15-01-2021; accepted: 30-01-2021

\begin{abstract}
The business competition for batik in Bangkalan is getting tougher because of the increasing business in batik, to be able to survive one way that can be used is to conduct business development by knowing consumer preferences. This research was conducted to determine the factors that influence consumer preferences of Tanjung Bumi batik in Tresna Art Gallery. Factors that influence consumer preferences can be seen from three things, that is based on product attributes, interests, and customer satisfaction. The sample of this study was 78 respondents with a period of data collection for 4 weeks. The results of the study say there are 3 factors that influence consumer preferences based on attributes that is esthetics, price perception, and price suitability with benefits. Consumer preferences based on interests are also influenced by 3 factors namely, lifestyle, profession, and family, while preferences based on customer satisfaction are only influenced by one factor, is the suitability of expectations. If viewed thoroughly, the factors that most influence consumer preference are conformity of expectations. Based on the results of the study it can be concluded that there are 7 factors that influence consumer preferences of Tanjung Bumi batik in Tresna Art Gallery, that is esthetics, price perception, price suitability with benefits, lifestyle, profession, family, and suitability of consumer expectations.
\end{abstract}

Keywords: factors; consumer preferences; batik of Tanjung Bumi

\begin{abstract}
Abstrak
Persaingan usaha batik tulis di Kabupaten Bangkalan semakin ketat karena bertambahnya usaha pada batik tulis, untuk dapat bertahan salah satu cara yang dapat digunakan adalah melakukan pengembangan usaha dengan mengetahui preferensi konsumen. Penelitian ini dilakukan untuk mengetahui faktor-faktor yang mempengaruhi preferensi konsumen batik tulis Tanjung Bumi di Galeri Tresna Art. Faktor yang mempengaruhi preferensi konsumen dapat dilihat dari tiga hal, yaitu berdasarkan atribut produk, kepentingan, serta kepuasan konsumen. Sampel penelitian ini sebanyak 78 responden dengan jangka waktu pengambilan data selama 4 minggu. Hasil penelitian mengatakan terdapat 3 faktor yang mempengaruhi preferensi konsumen berdasarkan atribut yaitu keindahan, persepsi harga, dan kesesuaian harga dengan manfaat. Preferensi konsumen berdasarkan kepentingan jugan dipengaruhi oleh 3 faktor yaitu, gaya hidup, profesi, serta keluarga sedangkan preferensi berdasarkan kepuasan konsumen hanya dipengaruhi oleh satu faktor saja yaitu kesesuaian harapan. Jika dilihat secara menyeluruh faktor yang paling mempengaruhi preferensi konsumen ialah kesesuaian harapan. Berdasarkan hasil penelitian tersebut dapat disimpulkan terdapat 7 faktor yang mempengaruhi preferensi konsumen batik tulis Tanjung Bumi di Galeri Tresna Art, yaitu keindahan, persepsi harga, kesesuaian harga dengan manfaat, gaya hidup, profesi, keluarga dan kesesuaian harapan konsumen
\end{abstract}

Kata kunci: faktor; preferensi konsumen; batik tulis Tanjung Bumi

\section{Pendahuluan}

Preferensi konsumen merupakan pilihan suka atau tidak suka yang sesuai dengan selera konsumen. Kotler (1997) mengatakan bahwa preferensi konsumen ialah pilihan terhadap sekumpulan produk berdasarkan tingkat kesukaan. Preferensi konsumen sangat penting karena dapat mempengaruhi keputusan pembelian. Maka dari itu, pihak produsen harus 
memiliki wawasan mengenai preferensi konsumen agar dapat mengembangkan usahanya menjadi lebih baik lagi.

Selain mengetahui bagaimana preferensi konsumen terhadap produk, pemilik usaha juga harus mengetahui faktor yang mempengaruhi preferensi tersebut. Widiyanto (2016) mengungkapkan untuk mengetahui faktor yang mempengaruhi preferensi konsumen dapat ditinjau dari 3 hal, yaitu atribut, kepentingan, serta kepuasan. Atribut berkaitan dengan unsur pada produk sebagai pertimbangan konsumen dalam keputusan pembelian, kepentingan berkaitan dengan kebutuhan dan keinginan konsumen, sedangkan kepuasan berkaitan dengan kualitas produk.Jabaran faktor yang mempengaruhi preferensi konsumen tersebut yang digunakan peneliti untuk mengetahui faktor apa saja yang mempengaruhi preferensi konsumen batik tulis Tanjung Bumi.

Sampai saat ini industri batik tulis di Kabupaten Bangkalan kurang melibatkan konsumen dalam pengembangan industri, dimana pelaku industri menawarkan produknya hanya berdasarkan keyakinan terhadap motif produk yang akan laku di pasaran (Rohman, 2010:82). Sebenarnya konsumen memiliki peran yang sangat penting dalam pengembangan usaha salah satunya dengan cara mengetahui preferensi konsumen. Berdasarkan hal tersebut penelitian ini dilakukan dengan tujuan untuk mengetahui faktor yang mempe ngaruhi preferensi konsumen agar dapat membantu pihak pemilik usaha mengembangkan usahanya, dalam penelitian ini pihak pemilik usaha ialah Galeri Tresna Art. Galeri Tresna Art dipilih sebagai tempat penelitian dikarenakan galeri tersebut merupakan salah satu galeri terbesar di Kabupaten Bangkalan.

\section{Metode}

Penelitian ini merupakan penelitian deskriptif dengan pendekatan kuantitatif. Variabel dalam penelitian ini hanya satu yaitu preferensi konsumen batik tulis Tanjung Bumi. Populasi penelitian berdasarkan rata-rata jumlah konsumen setiap bulannya yaitu 100 orang konsumen. Sampel diperoleh berdasarkan tabel Isaac dan Michael dengan taraf kesalahan 5\% (Sugiyono, 2016). Sesuai tabel tersebut dengan populasi 100 orang konsumen dengan taraf kesalahan $5 \%$ diperoleh sampel sebesar 78 orang konsumen.

Jenis data yang digunakan ialah data kuantitatif yang diperoleh dari hasil jawaban responden pada instrumen. Instrumen penelitian ini berbentuk angket tertutup. Langkah awal yang dilakukan dalam pengambilan data ialah mengecek kelayakan instrumen dengan cara uji validitas dan reliabilitas pada instrumen, hal tersebut bertujuan agar data yang dihasilkan valid dan reliabel. Diketahui semua item pertanyaan instrumen yang digunakan pada penelitian ini valid karena $r_{\text {hitung }}>0,361$ sedangkan dalam uji reliabilitas diperoleh nilai cronbach's alpha sebesar 0,784 yang lebih besar dari $r_{\text {tabel }} 0,61$ artinya instrumen tersebut reliabel.

Langkah selanjutnya ialah mengambil data di lapangan, dimana hasil data yang diperoleh akan diproses melalui beberapa tahapan. Tahapan tersebut terdiri dari, tabulsai data, perhitungan statistik, dan yang terakhir mendeskripsikan hasil perhitungan persentase dengan menginterpretasikannya.

\section{Hasil dan Pembahasan}

Gambaran responden penelitian ini adalah konsumen batik tulis Tanjung Bumi di Galeri tresan Art didominasi oleh perempuan, konsumen juga didominasi oleh konsumen yang berusia 18-40 tahun yang tegolong kategori usia dewasa awal. Hampir setengah dari 
konsumen memiliki profesi sebagai karyawan dan rata-rata penghasilan dari hampir setengah responden Rp1.000.000-Rp3.000.000 perbulan.

Tabel 1. Gambaran Umum Responden

\begin{tabular}{llcc}
\hline \multicolumn{1}{c}{ Kategori } & \multicolumn{1}{c}{ GambaranUmumResponden } & Frekuensi & Persentase \\
\hline JenisKelamin & Perempuan & 49 & $63 \%$ \\
Usia & Dewasa Awal (18 tahun - 40 tahun) & 48 & $62 \%$ \\
Pekerjaan & Karyawan & 30 & $38 \%$ \\
Pendapatan & Rp 1.000.000 - Rp. 3.000.000 & 36 & $46 \%$ \\
\hline
\end{tabular}

Motif batik tulis yang banyak dibeli oleh konsumen ialah motif Manok, artinya motif ini yang banyak disukai oleh konsumen.

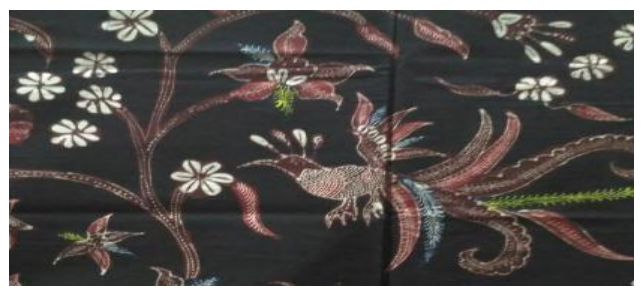

Gambar 1. Motif Manok

Faktor yang mempengaruhi preferensi konsumen ditinjau melalui 3 sub variabel, yaitu atribut, kepentingan, kepuasan konsumen. Berikut penjabaran hasil penelitian.

\subsection{Faktor yang Mempengaruhi Preferensi Konsumen Berdasarkan Atribut}

Faktor yang mempengaruhi preferensi konsumen berdasarkan atribut terdiri dari 4 indikator yaitu kualitas, citra merek, harga, dan desain, pada masing-masing indikator terdiri darai beberapa sub indikator. Indikator kualitas terdiri dari 2 sub indikator yaitu keindahan dan keunikan. Persentase tertinggi terdapat pada sub indikator keindahan sebesar 55\%. Indikator citra merek terdiri dari citra perusahaan dan citra produk, persentase tertinggi terdapat pada citra produk sebesar $35 \%$.

Indikator harga terdiri dari persepsi harga, kesesuaian harga dengan manfaat, keterjangkauan harga, persaingan harga, dan kesesuaian harga dengan kualitas. Persentase tertinggi pada indikator harga adalah persepsi harga dan kesesuaian harga dengan manfaat dengan besar persentase yang sama yaitu $54 \%$. Indikator desain terdiri dari motif dan warna, dimana persentase tertinggi diperoleh warna sebesar $50 \%$.

Berdasarkan penjabaran diatas diketahui faktor yang sangat mempengaruhi preferensi konsumen ialah keindahan, persepsi harga, dan kesesuaian harga dengan manfaat, hal tersebut dikarenakan persentase melebihi 50\%. Jika diinterpretasikan sebagian besar konsumen menyukai batik tulis Tanjung Bumi karena dipengaruhi oleh 3 faktor yaitu, keindahan, persepsi harga, serta kesesuaian harga dengan manfaat.

\subsection{Faktor yang Mempengaruhi Preferensi Konsumen Berdasarkan Kepentingan}

Berdasarkan kepentingan faktor yang mempengaruhi preferensi konsumen terdiri dari 2 indikator yaitu kebutuhan dan keinginan konsumen. Indikator kebutuhan terdiri dari sub 
indikator profesi, situasi ekonomi, dan keyakinan. Sub indikator profesi memiliki persentase tertinggi sebesar 56\%. Sedangkan indikator keinginan terdiri dari persepsi, usia, gaya hidup, budaya, keluarga, dan kelompok, pada indikator ini gaya hidup dan keluarga memiliki persentase tertinggi, masing-masing sebesar 58\% dan 53\%.

Merujuk dari uraian hasil penelitian diatas faktor yang mempengaruhi preferensi konsumen berdasarkan kepentingan yaitu profesi, gaya hidup, dan keluarga. Hal tersebut dapat diinterpretasikan hampir setengah dari konsumen Galeri Tresna Art menyukai batik tulis Tanjung Bumi karena pengaruh faktor profesi, gaya hidup, dan keluarga.

\subsection{Faktor yang Mempengaruhi Preferensi Konsumen Berdasarkan Kepuasan}

Terdapat 2 indikator untuk mengetahui faktor yang mempengaruhi preferensi konsumen berdasarkan kepuasan, yaitu kesesuaian harapan konsumen dan minat berkunjung kembali. Kedua indikator hanya terdiri dari sub indikator yang sama yaitu produk. Indikator kesesuaian harapan memiliki persentase tertinggi sebesar $64 \%$ sedangkan indikator minat berkunjung kembali memiliki persentase tertinggi sebesar 35\%. Hal tersebut dapat dikatakan bahwa kesesuaian harapan konsumen merupakan faktor yang mempengaruhi preferensi konsumen berdasarkan kepuasan. Sesuai dengan hasil tersebut dapat diinterpretasikan bahwa sebagian besar konsumen Galeri Tresna Art menyukai batik tulis Tanjung Bumi karena faktor kesesuaian harapan.

\subsection{Faktor yang Mempengaruhi Preferensi Konsumen Batik Tulis Tanjung Bumi di Galeri Tresna Art Bangkalan}

Hasil keseluruhan penelitian mengungkapkan bahwa preferensi sebagian besar konsumen Galeri Tresna Art terhadap batik tulis Tanjung Bumi dipengaruhi oleh 7 faktor, yaitu keindahan, persepsi harga, kesesuaian harga dengan manfaat, profesi, gaya hidup, keluarga, dan kesesuaian harapan. Kesesuaian harapan merupakan faktor yang sangat mempengaruhi preferensi konsumen diantara faktor yang lainnya.

Tabel 2. Hasil persentase tertinggi

\begin{tabular}{lc}
\hline \multicolumn{1}{c}{ Sub Indikator } & $\begin{array}{c}\text { Persentase Pilihan } \\
\text { Responden Terbanyak }\end{array}$ \\
\hline Keindahan & $55 \%$ \\
Keunikan & $50 \%$ \\
Citra Perusahaan & $33 \%$ \\
Citra Produk & $35 \%$ \\
Persepsi Harga & $54 \%$ \\
Kesesuaian Harga dengan Manfaat & $52 \%$ \\
Keterjangkauan Harga & $40 \%$ \\
Persaingan Harga & $46 \%$ \\
Kesesuaian Harga dengan Kualitas & $38 \%$ \\
Motif & $32 \%$ \\
Warna & $50 \%$ \\
Profesi & $56 \%$ \\
Situasi Ekonomi & $47 \%$ \\
Keyakinan & $38 \%$ \\
Persepsi & $40 \%$ \\
Usia & $32 \%$ \\
Gaya Hidup & $58 \%$
\end{tabular}


Jurnal Inovasi Teknik dan Edukasi Teknologi (JITET), 1(1), 2021, 64-70

\begin{tabular}{lc}
\hline \multicolumn{1}{c}{ Sub Indikator } & $\begin{array}{c}\text { Persentase Pilihan } \\
\text { Responden Terbanyak }\end{array}$ \\
\hline Budaya & $36 \%$ \\
Keluarga & $53 \%$ \\
Kelompok & $44 \%$ \\
Kesesuaian Harapan & $64 \%$ \\
Minat Kembali Berkunjung & $35 \%$ \\
\hline
\end{tabular}

Faktor yang mempengaruhi preferensi konsumen dapat ditinjau dari tiga aspek yaitu atribut produk, kepentingan, dan kepuasan. Aspek atribut terdiri dari empat indikator yaitu indikator kualitas yang terdiri dari keindahan dan keunikan, indikator citra merek yang terdiri dari citra perusahaan dan citra produk, indikator harga yang terdiri dari persepsi harga, kesesuaian harga dengan manfaat, persaingan harga, keterjangkauan harga, serta kesesuaian harga dengan kualitas, yang terakhir indikator desain yang terdiri dari warna serta motif. Hasil penelitian menunjukkan keindahan, persepsi harga, kesesuaian harga dengan manfaat merupakan faktor yang mempengaruhi preferensi konsumen pada aspek atribut.

Keindahan merupakan faktor yang sangat mempengaruhi pada aspek atribut. Hal tersebut sesuai dengan pernyataan Situmorang (2012) bahwa salah satu faktor yang mempengaruhi preferensi konsumen adalah estetika atau keindahan. Maka dari itu batik tulis yang memiliki keindahan akan banyak dipilih oleh konsumen, karena dapat menambah rasa percaya diri saat digunakan. Keindahan batik tulis Tanjung Bumi terletak pada perpaduan motif, warna, dan tekstur.

Persepsi harga dan kesesuaian harga dengan manfaat merupakan faktor yang dapat mempengaruhi preferensi konsumen juga, namun memberikan pengaruh lebih kecil daripada keindahan. Bertentangan dengan hasil penelitian Fauzi (2015) mengungkapkan bahwa kesesuaian harga dengan manfaat tidak menjadi ukuran dalam pengambilan keputusan. Hal tersebut dikarenakan manfaat pada produk sama dengan produk lainnya yang sejenis. Secara keseluruhan harga memiliki pengaruh terhadap pemilihan produk yang akan dibeli konsumen sama seperti pernyataan Gain (2017) yaitu harga memiliki pengaruh besar terhadap konsumen dalam pemilihan produk.

Berdasarkan hasil penelitian dapat diinterpretasikan sebagian besar konsumen menyukai batik tulis Tanjung Bumi di Galeri Tresna Art karena dipengaruhi faktor kualitas keindahan dan harga. Kualitas keindahan batik tulis Tanjung Bumi yang terletak pada perpaduan motif, warna, serta tekstur. Konsumen juga memiliki persepsi bahwa harga batik tulis Tanjung Bumi sesuai dengan kualitas dan manfaat yang diberikan.

Faktor yang mempengaruhi preferensi konsumen jika dilihat dari aspek kepentingan terdiri dari dua indikator yaitu kebutuhan dan keinginan. Indikator kebutuhan terdiri dari profesi, situasi ekonomi, dan keyakinan sedangkan keinginan terdiri dari gaya hidup, usia, persepsi, budaya, keluarga, dan kelompok. Hasil penelitian mengungkapkan bahwa faktor yang mempengaruhi preferensi konsumen jika ditinjau dari aspek kepentingan ialah gaya hidup, profesi, dan keluarga. Diantara ketiga faktor tersebut, gaya hidup memiliki persentase tertinggi yang dilanjutkan oleh profesi dan keluarga.

Lingkungan sekitar sangat berpengaruh terhadap gaya hidup konsumen dalam memilih produk yang akan dibeli. Konsumen memilih produk baik tulis Tanjung Bumi di Galeri Tresna 
Art karena desain pada batik tulis ini memiliki kesan bekelas sehingga memberikan rasa bangga pada konsumen saat mengenakannya. Hal tersebut menunjukkan bahwa konsumen ingin diakui oleh lingkungan sekitarnya. Pernyataan Rossif (2015) mengenai gaya hidup yang memiliki pengaruh positif terhadap preferensi konsumen dalam proses keputusan pembelian mendukung hasil penelitian ini.

Faktor yang mempengaruhi preferensi selanjutnya ialah profesi. Kebutuhan setiap profesi berbeda, maka dari itu profesi memiliki pengaruh dalam pemilihan produk barang yang akan dibeli konsumen. Pendapat Kotler dan Armstrong (2007) selaras dengan pernyataan tersebut, bahwa pekerjaan akan mempengaruhi pilihan barang atau jasa yang akan dibeli. Sesuai dengan gambaran umum konsumen Galeri Tresna Art, dimana sebagian besar konsumen memiliki profesi sebagai karyawan, mereka memilih batik tulis Tanjung Bumi karena desainnya cocok digunakan sebagai pakaian formal untuk bekerja.

Keluarga juga memberikan pengaruh dalam preferensi. Selera anggota keluarga menjadi salah satu pertimbangan dalam meilih barang yang dibeli. Seperti halnya hasil penelitian ini, konsumen memilih batik tulis Tanjung Bumi karena desain batik tulis sesuai dengan selera seluruh anggota keluarga. Serupa dengan pernyataan Towoliu (2017) keluarga memiliki pengaruh positif dan signifikan terhadap preferensi konsumen. Selain selera anggota keluarga, yang menjadi pertimbangan lain adalah referensi anggota keluarga berdasarkan pengalamannya saat membeli produk tersebut.

Hasil analisa diatas dapat diinterpretasikan sebagian besar konsumen menyukai batik tulis Tanjung Bumi jika ditinjau dari kepentingan ialah gaya hidup, profesi, dan keluarga. Gaya hidup mempengaruhi preferensi konsumen karena desain pada batik yang berkesan berkelas sehingga saat menggunakannya konsumen merasa bangga. Preferensi konsumen yang dipengaruhi profesi berkaitan dengan kebutuhan mereka terhadap busana kerja dimana desain batik tulis Tanjung Bumi cocok digunakan sebagai pakaian formal untuk bekerja, sedangkan keluarga memilih produk batik tulis Tanjung Bumi karena sesuai dengan selera semua anggota keluarga.

Faktor yang mempengaruhi preferensi konsumen jika ditinjau dari aspek kepuasan adalah kesesuaian harapan. Harapan konsumen yang terpenuhi akan menambah kepuasan konsumen terhadap produk yang dibeli. Penelitian ini mengungkapkan, harapan konsumen Galeri Tresna Art terhadap keindahan perpaduan motif dan warna batik tulis Tanjung Bumi. Kotler (1997) mengatakan perusahaan yang berhasil senantiasa meningkatkan harapan dan memberikan kinerja yang dapat memenuhi harapan konsumen. Pernyataan tersebut sesuai dengan hasil penelitian, dimana konsumen memilih berbelanja di Galeri Tresna Art karena pihak Tresna Art selalu memberikan kinerja produk batik tulis Tanjung Bumi melalui tampilan motif, warna, dan teksturnya dengan baik sehingga harapan konsumen dapat terpenuhi.

Pembahasan hasil penelitian diatas jika diinterpretasikan sebagian besar konsumen menyukai batik tulis Tanjung Bumi karena dipengaruhi oleh kesesuaian harapan. Kesesuaian harapan konsumen terletak pada keindahan perpaduan motif dan warna batik, sehingga kepuasan konsumen terhadap batik tulis Tanjung Bumi terpenuhi.

\section{Simpulan}

Hasil penelitian ini mengungkapkan bahwa gambaran umum konsumen batik tulis Tanjung Bumi di Galeri Tresna Art didominasi oleh perempuan serta didominasi oleh 
konsumen berusia 18-40 tahun yang tergolong ketegori dewasa awal. Hampir setengah dari konsumen memiliki profesi sebagai karyawan, dan rata-rata penghasilan hampir setengah konsumen perbulan yaitu Rp1.000.000-Rp3.000.000. Saat penelitian dilakukan terdapat 16 motif batik tulis Tanjung Bumi yang dibeli, namun motif Manok yang banyak dibeli oleh konsumen. Artinya, konsumen lebih menyukai motif Manok daripada motif yang lainnya. Terdapat tiga faktor yang mempengaruhi preferensi sebagian besar konsumen jika ditinjau dari aspek atribut yaitu keindahan, persepsi harga, dan kesesuaian harga dengan manfaat. Jika ditinjau dari aspek kepentingan terdapat tiga faktor juga yang mempengaruhi preferensi konsumen, ketiga faktor tersebut ialah gaya hidup, profesi, dan keluarga. Terakhir terdapat aspek kepuasanyang memiliki faktor tunggal dalam mempengaruhi preferensi konsumen, ialah faktor kesesuaian harapan konsumen. Berdasarkan penjabaran tersebut dapat disimpulkan bahwa terdapat tujuh faktor yang mempengaruhi sebagian besar preferensi konsumen, diantara ketujuh faktor tersebut, faktor kesesuaian harapan memiliki pengaruh lebih besar terhadap preferensi konsumen.

\section{Daftar Rujukan}

Fauzi, F. I. (2015). Pengaruh Dimensi Kualitas Produk, Harga, dan Citra Merek Terhadap Keputusan Pembelian Smartphone Android (Produk Samsung, Smartfren Andromax, dan Lenovo) Di Kabupaten Jember. Artikel Ilmiah Mahasiswa, hlm. 6. Dari: http://repository.unej.ac.id/bitstream/handle/123456789/64 430/FUADUL\%20ICHSAN\%@)FAUZI.pdf?sequence=1.

Gain, R., Herdinata, C., \& Sienatra, K. B. (2017). Pengaruh Kualitas Produk dan Harga terhadap keputusan pembelian konsumen Vodkasoda shirt. PERFORMA: Jurnal Manajemen dan Start-Up Bisnis, 2(2), 143150.

Kotler, P. (1997). Manajemen pemasaran: analisis, perencanaan, implementasi, dan kontrol. Jakarta: Prenhallindo.

Kotler \& Armstrong. (2007). Dasar Dasar Pemasaran, Edisi Kesembilan. Terjemahan Alexander Sindoro. Jakarta: PT. Indeks. 2001.

Rohman, R. (2010). Strategi Bisnis Usaha Batik Madura. Skripsi tidak diterbitkan. Surabaya: Fakultas Ilmu Sosial dan Ilmu Politik Universitas Pembangunan Nasional "Veteran" Jawa Timur.

Rosif, M. D. (2015). Analisis Gaya Hidup dalam Pengambilan Keputusan Pembelian Produk Batik pada Pasar Grosir Setono Pekalongan, 1-10. Dari: http://ejournals1.undip.ac.id/i ndex.php/

Situmorang, S. (2012). Analisis Keputusan Pembelian dan Preferensi Konsumen Batik Bogor Tradisiku. Skripsi tidak diterbitkan. Bogor: Fakultas Ekonomi dan Manajemen Institut Pertanian Bogor.

Sugiyono, S. (2016). Statistik untuk Penelitian. Bandung: Alfabeta.

Towoliu, J. E. S. (2017). Pengaruh Faktor Pribadi dan Faktor Keluarga terhadap Keputusan Pembelian Di Rumah Makan Waroeng Tepi Laut, Manado, 5(2), 308-322. Dari: https://ejournal.unsrat.ac.id/in dex.php/emba/article/view/15 618.

Widiyanto, N. A. (2016). Sikap, Preferensi dan Keputusan Pembelian Konsumen terhadap Buah Apel. Tesis tidak diterbitkan. Bogor: Pascasarjana Institut Pertanian Bogor. 